\title{
ABNORMAL RETURN DAN TRADING VOLUME ACTIVITY SAHAM-SAHAM LQ45 PADA PERISTIWA PENGUMUMAN KEBIJAKAN QUANTITATIVE EASING OLEH BANK SENTRAL AMERIKA SERIKAT
}

\author{
Muhammad Falih Ariyanto \\ Kantor Wilayah Direktorat Jenderal Perbendaharaan Provinsi Aceh \\ Alamat Korespondensi: falih.arieya@gmail.com
}

\section{INFORMASI ARTIKEL}

Diterima Pertama

23 Mei 2016

Dinyatakan Diterima

15 Juli 2016

\section{KATA KUNCI:}

Monetary Policy, Quantitative Easing, Financial Market, Event Study, Abnormal Return, Trading Volume Activity.

KLASIFIKASI JEL:

E4, E5, E6, F3, G14, G15

\section{ABSTRAK}

This research is an empirical study to analyze international event and its impacts on Indonesian capital market. The international event in this study is expansionary monetary policy issued by the Federal Reserve in the form of quantitative easing policies that were announced in three stages, on 26 November 2008, 4 November 2010, and 14 September 2012 (Indonesia Stock Exchange trading day). The study analyzed the abnormal return and trading volume activity occured at each event period. Observation period in this study used 120-day estimation period and 11day event period at each stage of the quatitative easing announcement. The event study was done in Indonesian capital market represented by 127 shares that are catagorized as LQ45 index and actively traded in each event period. The assumption that Indonesian capital market is co-integrated with international capital market can make the announcement of quantitative easing policy as positive information for investors in Indonesia. The analysis results show that a significant positive abnormal return around the event date and a significant increase in the intensity trading activities after the quantitative easing announcement, occured. The market test results show that Indonesian capital market has efficient information in a semi-strong form, so that the investors cannot use the published information to get profits (positive abnormal return) in a long run (around the date of the event only).

Penelitian ini merupakan studi empiris untuk menganalisis peristiwa internasional dan dampaknya terhadap pasar modal Indonesia. Peristiwa internasional yang diteliti adalah pengumuman kebijakan moneter ekspansif yang dikeluarkan oleh Bank Sentral Amerika Serikat, yaitu quantitative easing yang dilakukan dalam tiga tahapan pengumuman pada tanggal 26 November 2008, 4 November 2010 dan 14 September 2012 (hari perdagangan bursa di Indonesia). Penelitian dilakukan dengan menganalisis abnormal return dan trading volume activity yang terjadi disetiap periode peristiwa. Penelitian ini menggunakan periode pengamatan yang terdiri dari 120 hari periode estimasi dan 11 hari periode peristiwa disetiap tahapan pengumuman quantitative easing. Analisis studi peristiwa dilakukan pada pasar modal Indonesia yang diwakili oleh 127 saham yang pernah masuk dalam kategori indeks LQ45 dan secara aktif diperdagangkan disetiap periode peristiwa. Asumsi bahwa pasar modal Indonesia terkointegrasi dengan pasar modal internasional menyebabkan pengumuman kebijakan quantitative easing dapat menjadi informasi yang positif bagi pemodal di Indonesia. Hasil analisis menunjukkan bahwa terjadi abnormal return positif yang signifikan di sekitar tanggal peristiwa dan peningkatan intensitas perdagangan yang signifikan setelah peristiwa pengumuman kebijakan quantitative easing. Hasil pengujian efisiensi pasar menunjukkan bahwa pasar modal Indonesia efisien secara informasi dalam bentuk setengah kuat sehingga pemodal tidak dapat menggunakan informasi yang dipublikasikan untuk mendapatkan keuntungan (abnormal return positif) dalam jangka waktu yang lama (hanya di sekitar tanggal peristiwa). 


\section{PENDAHULUAN}

\subsection{Latar Belakang}

Pada tahun 2008, Amerika Serikat mengalami krisis subprime mortgage yang berakibat pada kebangkrutan beberapa lembaga keuangan. Untuk mengatasi masalah tersebut, The Fed meluncurkan kebijakan yang dinilai tidak biasa yaitu kebijakan stimulus berupa pelonggaran moneter (Quantitative Easing) dengan melakukan pembelian Mortgage Backed Securities (MBS) dan Treasury Notes.

Quantitative easing diputuskan oleh Federal Open Market Committee (FOMC) yang berada di bawah kendali The Fed dan diumumkan pada tanggal 25 November 2008 untuk kebijakan quantitative easing tahap pertama, 3 November 2010 untuk kebijakan quantitative easing tahap kedua, dan 13 September 2012 untuk kebijakan quantitative easing tahap ketiga. Lembaga keuangan di Amerika Serikat yang memperoleh uang tunai dari kebijakan quantitative easing tersebut akan menggunakan dana yang dimilikinya untuk memperoleh keuntungan. Cara yang dilakukan antara lain dengan menyalurkan kembali dana tersebut dalam bentuk kredit perbankan dan kemudian memperoleh keuntungan dari pembayaran bunga pinjaman.

Cara lain yang dilakukan oleh lembaga keuangan tersebut adalah menyalurkan dana melalui berbagai instrumen investasi diluar Amerika Serikat akibat terjadinya surplus mata uang dan pelemahan nilai Dollar Amerika Serikat sehingga pemodal di Amerika Serikat mengalihkan investasi ke negara-negara berkembang yang memiliki tingkat pertumbuhan ekonomi tinggi. Statistik Pasar Modal yang dikeluarkan oleh Badan Pengawas Pasar Modal dan Lembaga Keuangan (Bapepam-LK) menyebutkan bahwa terjadi peningkatan nilai perdagangan yang dilakukan oleh pemodal asing di Bursa Efek Indonesia (BEI) di sekitar tanggal peristiwa pengumuman kebijakan quantitative easing.

Pasar modal Indonesia yang terkointegrasi dengan pasar modal di Amerika Serikat menyebabkan kebijakan quantitative easing berdampak pada kinerja bursa saham di Indonesia. Dampak kebijakan quantitative easing bagi pasar modal Indonesia adalah limpahan dana melalui aktivitas pemodal asing yang melakukan transaksi perdagangan saham di Indonesia. Data LQ45 memperlihatkan pergerakan harga yang berbeda antara periode sebelum dan sesudah pengumuman paket kebijakan tersebut.

Adanya reaksi pergerakan indeks LQ45 di sekitar periode pengumuman dapat diteliti dengan menggunakan metode studi peristiwa untuk menguji kandungan informasi dari suatu peristiwa. Pengukuran yang biasa digunakan dapat menggunakan abnormal return yang menunjukkan adanya perubahan harga dari saham yang diteliti (Dyckman, 1984). Jika peristiwa tersebut mempunyai kandungan informasi bagi pemodal maka peristiwa tersebut memberikan reaksi bagi pasar modal dalam bentuk abnormal return dan intensitas perdagangan melalui trading volume activity yang meningkat.

\section{KERANGKA TEORI DAN PENGEMBANG- AN HIPOTESIS}

\subsection{Quantitative Easing}

Quantitative easing dilakukan ketika tingkat bunga berada di tingkat yang sangat rendah karena pada kondisi tersebut Bank Sentral tidak mungkin untuk mengeluarkan kebijakan moneter melalui penurunan tingkat suku bunga. Untuk melakukan intervensi pasar, Bank Sentral melakukan pembelian obligasi pemerintah dari sektor perbankan dengan tujuan meningkatkan cadangan likuiditas pada lembaga keuangan. Paket kebijakan quantitative easing yang telah diumumkan oleh FOMC setelah krisis keuangan di Amerika Serikat terangkum dalam Tabel 1.

Tabel 1. Ringkasan Pernyataan FOMC tentang Paket Kebijakan Quantitative Easing

\begin{tabular}{|l|l|l|}
\hline No. & \multicolumn{1}{|c|}{$\begin{array}{c}\text { Tanggal } \\
\text { Pernyataan }\end{array}$} & \multicolumn{1}{c|}{ Paket Kebijakan } \\
\hline 1. & $\begin{array}{l}\text { Tahap I: } \\
25 \text { November 2008 }\end{array}$ & $\begin{array}{l}\text { The Fedakan membeli T- } \\
\text { Notes, MBS dan obligasi } \\
\text { perbankan. Pembelian } \\
\text { dilakukan bertahap dan } \\
\text { mencapai US } \$ 2.1 \text { Trilyun } \\
\text { pada Juni 2010. }\end{array}$ \\
\hline 2. & $\begin{array}{l}\text { Tahap II: } \\
\text { 03 November 2010 }\end{array}$ & $\begin{array}{l}\text { The Fed akan membeli aset } \\
\text { sebesar US } \$ 75 \text { Milyar per } \\
\text { bulan sampai dengan } \\
\text { bulan Juni 2011. }\end{array}$ \\
\hline 3. & $\begin{array}{l}\text { Tahap III: } \\
13 \text { September 2012 }\end{array}$ & $\begin{array}{l}\text { The Fed akan membeli MBS } \\
\text { sebesar US } \$ 40 \text { Milyar per } \\
\text { bulan dan tetap } \\
\text { menjalankan kebijakan QE } \\
\text { Tahap II. Total pembelian } \\
\text { yang dilakukan The Fed } \\
\text { mencapai US } \$ 85 \text { Milyar } \\
\text { per bulan. }\end{array}$ \\
\hline
\end{tabular}

Sumber: diolah dari Federal Reserve Press Release.

\subsection{Kointegrasi Pasar Modal Indonesia}

Ekonomi dunia yang semakin terintegrasi menyebabkan hampir seluruh negara di dunia termasuk Indonesia terpengaruh dengan aliran modal antar negara. Menurut penelitian yang dilakukan oleh Bapepam-LK (2008) menyebutkan bahwa terdapat hubungan antara aliran masuk modal asing (capital inflow) ke Indonesia dengan pergerakan IHSG yang berpengaruh secara positif. ${ }^{1}$ Penelitian yang

1 Badan Pengawas Pasar Modal dan Lembaga Keuangan, Analisis Hubungan Kointegrasi Dan Kausalitas Serta Hubungan Dinamis Antara Aliran Modal Asing, Perubahan Nilai Tukar Dan 
dilakukan Abimanyu (2008) menemukan bahwa pasar modal Indonesia mempunyai hubungan secara internasional dengan pasar saham antara lain pasar saham di negara-negara ASEAN (Malaysia, Singapura dan Thailand), pasar saham negara-negara Asia Pasifik (Tiongkok, Korea, Jepang, Hongkong dan Taiwan), pasar saham di Amerika Serikat dan pasar saham di negara-negara Eropa Barat (Perancis, Jerman, Belanda dan Inggris). ${ }^{2}$

\subsection{Actual Return}

Kenaikan harga saham akan memberikan return positif dan penurunan harga saham akan memberikan return negatif bagi investor. Menurut Hartono (2013), actual return dapat berupa capital gain atau capital loss yang merupakan selisih dari harga sekuritas terhadap harga dalam periode yang lalu. ${ }^{3}$ Return saham $\left(R_{i, t}\right)$ diperoleh dari harga saham harian $\left(P_{i, t}\right)$ sekuritas $i$ pada periode $t$, dikurangi harga saham $\left(P_{i, t-1}\right)$ sekuritas $i$ pada periode $t-1$, dibagi harga saham harian $\left(P_{i, t-1}\right)$ sekuritas $i$ pada periode $t-1$. Actual return tersebut dapat dijelaskan dengan persamaan sebagai berikut:

$$
R_{i, t}=\frac{P_{i, t}-P_{i, t-1}}{P_{i, t-1}}
$$

\subsection{Expected Return}

Expected return merupakan return yang diharapkan oleh investor. ${ }^{4}$ Salah satu model yang dapat digunakan untuk memperoleh estimasi return pada periode peristiwa adalah Market Model. Tahapan dalam menghitung return ekspektasi dengan market model dilakukan dengan 2 langkah. Pertama, membuat model ekspektasi dengan menggunakan data realisasi selama periode estimasi. Kedua, dengan menggunakan model ekspektasi dari hasil langkah pertama untuk digunakan mengestimasi return ekpektasi pada periode peristiwa.

Untuk membentuk model ekspektasi dapat digunakan teknik regresi Ordinary Least Square (OLS) dengan persamaan sebagai berikut:

$R_{i, j}=\propto_{i}+\beta_{i}\left(R_{M, j}\right)+\epsilon_{i, j}$

Keterangan:

$R_{i, j}$ : Return realisasi sekuritas ke-i pada periode estimasi ke-j

Pergerakan IHSG Di Pasar Modal Indonesia, (Jakarta: Bapepam-LK, 2008).

2 Yoopi Abimanyu et al, International Linkages to the Indonesian Capital Market: Cointegration Test, (Jakarta: Capital Market and Financial Institution Supervisory Agency, 2008).

3 Jogiyanto Hartono, Teori Portofolio dan Analisis Investasi, Edisi ke-8, (Yogyakarta: BPFE, 2013), hlm. 64 .

4 Ibid., hlm.69. $\propto_{i} \quad$ : Intercept untuk sekuritas ke-i

$\beta_{i}$ : Koefisien slop yang merupakan Beta dari sekuritas ke-i

$R_{m, j}:$ Return indeks pasar pada periode estimasi ke-j

$\epsilon_{i, j}:$ Kesalahan residu sekuritas ke-i pada periode estimasi ke-j

Return pasar dapat dihitung berdasarkan nilai indeks LQ45 dengan persamaan sebagai berikut:

$$
R_{M, t}=\frac{L Q 45_{t}-L Q 45_{t-1}}{L Q 45_{t-1}}
$$

\subsection{Abnormal Return}

Hartono (2013) menjelaskan bahwa abnormal return $\left(A R_{i, t}\right)$ merupakan selisih antara actual return $\left(R_{i, t}\right)$ dan return normal yang merupakan return yang diharapkan oleh investor $E\left(R_{i, t}\right) .^{5}$ Model yang digunakan adalah:

$$
A R_{t, i}=R_{i, t}-E\left(R_{i, t}\right)
$$

\subsection{Trading Volume Activity}

Beaver (1968) dan Morse (1981) menjelaskan bahwa peristiwa yang memiliki kandungan informasi dapat mempengaruhi investor untuk membeli lebih banyak saham atau menjual sebagian saham yang telah dimiliki. Oleh karena itu, reaksi yang ditimbulkan oleh suatu peristiwa yang memiliki kandungan informasi dapat ditunjukkan melalui perubahan volume perdagangan. Perubahan aktivitas volume perdagangan (trading volume activity) dapat dilihat dari perbandingan antara jumlah saham yang diperdagangkan dengan jumlah saham yang beredar yang dapat dapat diukur dengan formulasi sebagai berikut:

$V_{i, t}=\frac{\sum \text { Saham diperdagangkan pada waktu } t}{\sum \text { Saham yang beredar pada waktut }}$

\subsection{Studi Peristiwa}

Menurut Hartono (2013), studi peristiwa dapat digunakan untuk mengukur kandungan informasi dari suatu peristiwa. ${ }^{6}$ Jika suatu peristiwa memiliki kandungan informasi, maka pasar akan bereaksi melalui abnormal return. Selain itu, studi peristiwa dapat digunakan untuk pengujian efisiensi pasar sebagai pengujian lanjutan dari pengujian kandungan informasi untuk mengukur kecepatan rekasi pasar atas informasi suatu peristiwa. Pasar dikatakan efisien secara informasi jika suatu peristiwa atau informasi dapat direspon dengan cepat oleh pasar.

Dalam mengukur pasar yang efisien berpedoman pada hubungan harga sekuritas dan informasi. Bodie $(2011)^{7}$ dan Hartono $(2013)^{8}$

5 Ibid., hlm.93.

6 Ibid., hlm.7.

7 Zvi Bodie, et al, Investment and Portofolio Management, $9^{\text {th }}$ edition, (New York: McGraw Hill, 2011), hlm. 375.

8 Hartono, Loc Cit. hlm. 548. 
menjelaskan mengenai bentuk-bentuk efisiensi pasar yang dibedakan ke dalam 3 kategori antara lain (1) Efisiensi pasar bentuk lemah (weak form), yaitu apabila harga-harga saham menggambarkan seluruh informasi yang berasal dari periode masa lalu sehingga investor tidak dapat menggunakan informasi masa lalu untuk memperoleh abnormal return, (2) Efisiensi pasar bentuk setengah kuat (semi-strong form) yaitu apabila harga-harga saham secara penuh mencerminkan semua informasi yang dipublikasikan termasuk juga informasi mengenai prospek perusahaan ke depan sehingga pemodal tidak dapat menggunakan informasi yang dipublikasikan untuk mendapatkan abnormal return dalam jangka waktu yang lama, (3) Efisiensi pasar bentuk kuat (strong form) yaitu apabila harga-harga saham secara penuh mencerminkan informasi yang tersedia termasuk juga informasi yang hanya diketahui oleh pihak internal perusahaan (insider information) sehingga investor tidak dapat memperoleh abnormal return hanya dengan memiliki informasi internal perusahaan.

\subsection{Penelitian Terdahulu}

Penelitian terdahulu mengenai hubungan kebijakan moneter terhadap pasar modal serta hubungan arus modal asing terhadap pasar modal antara lain dilakukan oleh Rigobon (2003) yang melakukan penelitian mengenai reaksi pasar modal terhadap kebijakan moneter yang dikeluarkan oleh Bank Sentral. Hasil penelitian menunjukkan bahwa kebijakan moneter berdampak pada pasar modal dipengaruhi melalui dua saluran. Pertama, dipengaruhi oleh pernyataan yang dikeluarkan oleh Gubernur Bank Sentral. Kedua, pergerakan harga saham dipengaruhi oleh naik turunnya suku bunga acuan yang berdampak pada biaya modal.

Penelitian yang dilakukan Conover (2005) melalui obervasi pada kebijakan moneter yang dikeluarkan oleh The Fed pada periode 19 Juli 1963 sampai dengan 2 Januari 2001 menemukan bahwa kebijakan moneter yang ekspansif mempunyai hubungan yang kuat dengan return sekuritas. Return saham di Amerika Serikat meningkat secara konsinsten dan relatif stabil ketika The Fed mengumumkan kebijakan moneter ekspansif dan berpengaruh secara global. Menurut hasil penelitian, para profesional menjadikan kondisi moneter sebagai pertimbangan dalam melakukan analisis fundamental perdagangan sekuritas di pasar AS dan Internasional.

\subsection{Pengembangan Hipotesis}

Berdasarkan latar belakang dan kajian literatur, maka dapat dirumuskan hipotesis penelitian sebagai berikut:

\footnotetext{
$H_{1}$ : Terdapat abnormal return yang positif pada saham-saham LQ45 selama periode peristiwa pengumuman kebijakan $Q E$.
}

\section{$\mathrm{H}_{2}$ : Terdapat rata-rata trading volume activity yang lebih besar pada saham-saham LQ45 sesudah pengumuman kebijakan $Q E$.}

\section{METODOLOGI PENELITIAN}

\subsection{Sampel}

Penelitian ini menggunakan sampel perusahaan yang termasuk dalam indeks LQ45 di BEI. Pemilihan indeks LQ45 disebabkan karena penelitian dengan metode studi peristiwa yang menggunakan data harian memerlukan data sekuritas yang mempunyai tingkat likuiditas tinggi dan nilai kapitalisasi pasar besar. Teknik penyampelan menggunakan metode purposive sampling yaitu pemilihan sampel dengan kriteria tertentu. Kriteria yang digunakan sebagai berikut:

3.1.1 Sekuritas yang telah terdaftar dalam indeks LQ45 pada periode perdagangan pengumuman paket kebijakan quantitative easing tahap I, II dan III.

3.1.2 Perusahaan yang tidak melakukan corporate action (pembagian dividen, stock split dan right issue) selama periode peristiwa. Hal tersebut perlu dilakukan untuk menghindari adanya peristiwa pengganggu (comfounding effects) yang mengganggu validitas reaksi pasar.

Berdasarkan kriteria tersebut, diperoleh jumlah sampel saham LQ45 sebanyak 127 sekuritas yang dapat dikategorikan meliputi 42 sampel sekuritas pada peristiwa quantitative easing Tahap I, 40 sampel sekuritas pada peristiwa quantitative easing Tahap II dan 45 sampel sekuritas pada peristiwa quantitative easing Tahap III.

\subsection{Metode Pengumpulan Data}

Data yang digunakan dalam penelitian ini merupakan data sekunder yang diperoleh antara lain dari Bloomberg, www.idx.co.id, dan finance.yahoo.com. Data tersebut kemudian dipilih dengan langkah sebagai berikut:

3.2.2. Data saham yang digunakan merupakan saham-saham LQ45 yang sesuai dengan kriteria penyampelan.

3.2.3. Data saham merupakan harga saham penutupan harian, volume perdagangan, dan jumlah saham yang beredar selama periode penelitian.

3.2.4. Data harga saham harian dikumpulkan selama periode $t-125$ atau 125 hari sebelum diumumkan kebijakan quantitative easing Tahap I, II dan III oleh The Fed sampai dengan $t+5$ atau 5 hari setelah diumumkan kebijakan quantitative easing Tahap I, II dan III oleh The Fed.

3.2.5. Data volume perdagangan dan jumlah saham yang beredar dikumpulkan selama periode peristiwa yaitu $t-5$ atau 5 hari sebelum pengumuman sampai dengan $t+5$ atau 5 hari 
setelah diumumkan kebijakan quantitative easing Tahap I, II dan III oleh The Fed.

Periode waktu yang digunakan dalam penelitian ini adalah selama 131 hari bursa yang terdiri dari 2 periode, yakni periode estimasi dan periode peristiwa. Tanggal peristiwa $\left(t_{0}\right)$ ditetapkan 1 hari bursa setelah peristiwa kebijakan quantitative easing diumumkan oleh The Fed karena adanya perbedaan waktu perdagangan bursa di Amerika Serikat dan Indonesia.

Statistik deskriptif data abnormal return selama periode peristiwa terangkum sebagaimana Lampiran I menunjukkan bahwa pada peristiwa quantitative easing tahap I terdapat rata-rata abnormal return yang positif pada $t_{-3}$ dan $t_{-1}$. Kemudian statistik deskriptif pada peristiwa II menunjukkan adanya rata-rata abnormal return positif yang jumlahnya lebih banyak dari peristiwa I antara lain pada pada $t_{-5}$, $t_{-3}, t_{-2}, t_{-1}, t_{0}, t_{+1}$ dan $t_{+5}$. Sedangkan pada peristiwa III sebagian besar tanggal di sekitar tanggal peristiwa memiliki rata-rata abnormal return positif, namun masih terdapat abnormal return negatif pada hari $\mathrm{t}_{-4}$ dan $t_{+2}$

Statistik deskriptif rata-rata trading volume activity selama periode peristiwa terangkum sebagaimana Lampiran II menunjukkan bahwa puncak intensitas perdagangan saham pada peristiwa quantitative easing tahap I dan III terjadi pada hari peristiwa pengumuman kebijakan $\left(\mathrm{t}_{0}\right)$ yaitu sebesar 0,010405 dan 0,004368 . Akan tetapi, pada peristiwa II nilai rata-rata trading volume activity tertinggi terjadi sehari setelah peristiwa pengumuman $\left(\mathrm{t}_{+1}\right)$ sebesar 0,005748 dan intensitas perdagangan sahamsaham yang menjadi sampel pada peristiwa II tersebut cenderung datar.

\subsection{Pengujian Hipotesis}

\subsubsection{Pengujian Hipotesis I}

Menurut Hartono (2013), pengujian abnormal return yang menggunakan market model dalam penentuan expected return dapat menggunakan pengujian- $t$ untuk menguji hipotesis nol bahwa abnormal return adalah lebih besar dari nol. ${ }^{9}$ Langkah pengujian- $t$ tersebut dilakukan antara lain dengan menghitung deviasi standar masing-masing sekuritas $\left(\sigma_{i}\right)$, menghitung nilai abnormal return terstandardisasi untuk sekuritas ke-i pada waktu ke- $t$ $\left(\mathrm{SAR}_{i, t}\right)$ dan terakhir menghitung nilai $t$. Pengujian- $t$ dilakukan untuk return portofolio melalui rata-rata return semua sekuritas pada hari ke- $t$ selama periode peristiwa. $S A R_{t}$ portofolio $k$-buah sekuritas untuk periode ke- $t$ juga merupakan nilai statistik $t$ ( $t$-hitung $)$ yang dapat dihitung dengan formula sebagai berikut:

$t_{- \text {hitung }}=S A R_{t}=\frac{\sum_{i-1}^{k} S A R_{i, t}}{\sqrt{k}}$

\footnotetext{
${ }^{9}$ Jogiyanto Hartono, Op.Cit., hml. 117
}

Untuk membuktikan hipotesis pertama digunakan pengujian- $t$ dengan satu sampel yang bertujuan untuk melihat apakah nilai abnormal return yang positif mempunyai signifikansi. Pertimbangan yang digunakan untuk pengambilan keputusan menerima atau menolak $\mathrm{H}_{0}$ dalam pengujian satu arah (one tailed) sisi kanan sebagai berikut:

a. Jika nilai $t_{\text {-hitung }}>t_{\text {-tabel }}$ maka $\mathrm{H}_{0}$ ditolak yang artinya terdapat abnormal return yang positif dan signifikan.

b. Jika $t_{\text {-hitung }}<t_{\text {-tabel, }}$ maka $\mathrm{H}_{0}$ tidak dapat ditolak artinya tidak terdapat abnormal return yang positif dan signifikan.

\subsubsection{Pengujian Hipotesis II}

Hipotesis kedua menguji rata-rata trading volume activity yang lebih besar pada saham-saham LQ45 sesudah pengumuman kebijakan QE. Langkahlangkah pengujian yang dilakukan sebagai berikut:

a. Menghitung rata-rata trading volume activity $\left(V_{i, t}\right)$ sebelum dan sesudah peristiwa.

b. Menghitung rata-rata selisih antara trading volume activity $(\bar{d})$ yang berpasangan.

c. Menghitung deviasi standar dari rata-rata selisih antara trading volume activity $\left(S_{d}\right)$ yang berpasangan dengan menggunakan formula sebagai berikut:

$S_{d}=\sqrt{\frac{\sum_{t-5}^{t-1}(d-\bar{d})^{2}}{t-1}}$

d. Uji statistik untuk menghitung nilai $t_{\text {-hitung }}$ diperoleh dengan formula sebagai berikut:

$t_{- \text {hitung }}=\frac{\bar{d}}{s_{d} / \sqrt{t}}$.

Untuk membuktikan hipotesis kedua, digunakan uji beda satu arah (one tailed) sisi kiri dengan sampel yang berhubungan (paired sample t-test) dengan

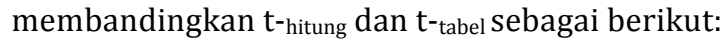

a. Jika t-hitung $<\mathrm{t}$-tabel, maka $\mathrm{H}_{0}$ ditolak yang artinya terdapat rata-rata trading volume activity yang lebih besar dan signifikan pada saham-saham LQ45 sesudah peristiwa.

b. Jika t-hitung $>$ t-tabel, maka $\mathrm{H}_{0}$ tidak dapat ditolak artinya tidak terdapat rata-rata trading volume activity yang lebih besar dan signifikan pada saham-saham LQ45 sesudah peristiwa.

\section{HASIL PENELITIAN}

Pengujian hipotesis menggunakan pengujian-t untuk menguji keberadaan abnormal return dan trading volume activity selama periode peristiwa. Pengujian statistik yang digunakan adalah pengujian secara parametrik karena distribusi data yang diuji menggunakan uji normalitas Kolmogorov-Smirnov selama periode peristiwa terdistribusi normal. Pengujian hipotesis pertama dilakukan untuk membuktikan apakah pemodal mendapatkan 
abnormal return positif akibat peristiwa pengumuman kebijakan quantitatve easing pada tahap I, II dan III. Prosedur pengujian- $t$ dilakukan

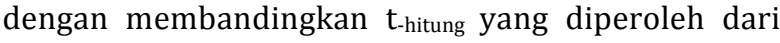
rata-rata abnormal return terstandarisasi semua sekuritas yang menjadi sampel penelitian dengan menggunakan persamaan (3.1). Tabel 2 menampilkan perbandingan nilai $\mathrm{t}_{\text {-hitung }}$ dan nilai kritis ( $\mathrm{t}_{\text {-tabel }}$ ) pada pengujian hipotesis pertama.

Tabel 2.Uji Signifikansi Rata-Rata Abnormal Return

\begin{tabular}{|c|l|l|l|l|l|l|}
\hline & \multicolumn{2}{|c|}{ Tahap I } & \multicolumn{2}{c|}{ Tahap II } & \multicolumn{2}{c|}{ Tahap III } \\
\hline t & Rata-rata AR & t-hitung & Rata-rata AR & t-hitung & Rata-rata AR & t-hitung \\
\hline-5 & $-0,014856$ & $-1,5822$ & 0,002870 & 0,7756 & 0,000617 & 0,1111 \\
\hline-4 & $-0,008116$ & $-0,7555$ & $-0,001557$ & $-0,5342$ & $-0,002410$ & $-0,6005$ \\
\hline-3 & $0,003838 * * *$ & 0,2926 & 0,003949 & 0,4788 & 0,005806 & 1,6729 \\
\hline-2 & $-0,010160$ & $-0,6438$ & 0,006390 & 1,1748 & $0,008694 * *$ & 2,2383 \\
\hline-1 & $0,017425 * * *$ & 2,4375 & 0,000128 & $-0,2414$ & 0,004691 & 0,9322 \\
\hline 0 & $-0,015931$ & $-1,9827$ & 0,003668 & 1,0490 & $0,007531 * *$ & 1,9152 \\
\hline 1 & $-0,011134$ & $-1,1313$ & 0,001918 & 0,3621 & 0,005712 & 1,2854 \\
\hline 2 & $-0,005632$ & $-0,6164$ & $-0,002583$ & $-0,0817$ & $-0,002651$ & $-0,8440$ \\
\hline 3 & $-0,004565$ & $-0,3987$ & $-0,002817$ & $-0,3548$ & $0,012885^{* * *}$ & 3,0372 \\
\hline 4 & $-0,003429$ & $-0,5238$ & $-0,000970$ & $-0,1641$ & 0,005818 & 1,5953 \\
\hline 5 & $-0,003967$ & $-0,5580$ & 0,005384 & 0,7258 & 0,001664 & 0,2533 \\
\hline
\end{tabular}

Keterangan: ** Signifikan pada tingkat 5\%

*** Signifikan pada tingkat 1\%

Tahap I : nilai kritis $t-(\alpha=0,05, d f=41)=1,683$ dan $t_{-(\alpha=0,01, d f=41)}=2,421$

Tahap II : nilai kritis $t-(\alpha=0,05, d f=39)=1,685$ dan $t_{-(\alpha=0,01, d f=39)}=2,426$

Tahap III : nilai kritis $t-(\alpha=0,05, d f=44)=1,680$ dan $t-(\alpha=0,01, d f=44)=2,414$

Hasil pengujian hipotesis I menunjukkan bahwa terdapat abnormal return positif dan signifikan disekitar tanggal peristiwa pengumuman kebijakan quantitative easing I dan III. Pada peristiwa pengumuman kebijakan quantitative easing I, abnormal return yang positif terjadi di hari $\mathrm{t}_{-3}$ dan $\mathrm{t}$ 1pada tingkat signifikansi 1 persen. Akan tetapi, abnormal return positif pada peristiwa II terdapat di $\mathrm{t}_{-5}, \mathrm{t}_{-3}, \mathrm{t}_{-2}, \mathrm{t}_{0}, \mathrm{t}_{+1}$ dan $\mathrm{t}_{+5}$ dan tidak signifikan. Pada peristiwa III, abnormal return positif dan signifikan terdapat di $\mathrm{t}_{-2}$ dan $\mathrm{t}_{-0}$ dengan tingkat signifikansi 5 persen dan pada $t_{+3}$ dengan tingkat signifikansi 1 persen.

Hipotesis kedua adalah menguji intensitas perdagangan melalui rata-rata trading volume activity yang lebih besar sesudah peristiwa pengumuman kebijakan quantitative easing tahap I, II dan III. Tabel 3 menampilkan hasil pengujian-t rata-rata trading volume activity sebelum dan sesudah peristiwa pengumuman quantitative easing tahap I, II dan III.

Tabel 3. Uji Signifikansi Rata-Rata Trading Volume Activity

\begin{tabular}{|c|c|c|c|c|c|}
\hline & & Rata-rata TVA & $\sigma$ TVA & $\mathbf{N}$ & $t_{\text {-hitung }}$ \\
\hline \multirow[t]{2}{*}{ Tahap I } & Sebelum & 0,005712 & 0,0133441 & \multirow{2}{*}{42} & \multirow{2}{*}{$-2,197 * *$} \\
\hline & Sesudah & 0,007198 & 0,0146822 & & \\
\hline \multirow[t]{2}{*}{ Tahap II } & Sebelum & 0,004315 & 0,0068020 & \multirow{2}{*}{40} & \multirow{2}{*}{$-1,253$} \\
\hline & Sesudah & 0,004825 & 0,0072370 & & \\
\hline \multirow[t]{2}{*}{ Tahap III } & Sebelum & 0,002418 & 0,0030786 & \multirow{2}{*}{45} & \multirow{2}{*}{$-2,367 * *$} \\
\hline & Sesudah & 0,002882 & 0,0031766 & & \\
\hline
\end{tabular}

Keterangan : ** Signifikan pada tingkat 5\%

Tahap I : nilai kritis $t_{-}(\alpha=0,05, d f=41)=-1,683$

Tahap II : nilai kritis $t_{-}(\alpha=0,05, d f=39)=-1,685$

Tahap III : nilai kritis $t-(\alpha=0,05, d f=44)=-1,680$

Hasil pengujian menunjukkan bahwa pada peristiwa quantittaive easing tahap I dan III terdapat rata-rata trading volume activity sesudah pengumuman peristiwa yang lebih besar dibandingkan sebelum peristiwa dan signifikan pada tingkat kepercayaan 5 persen. Akan tetapi, hasil pengujian pada peristiwa II menunjukkan hanya terdapat rata-rata trading volume activity yang lebih besar sesudah peristiwa namun tidak signifikan.

Hasil pengujian- $t$ pada abnormal return selama periode peristiwa quantitative easing tahap I, II dan III menunjukkan bahwa hanya terdapat abnormal return positif dan signifikan pada periode di sekitar pengumuman quantitative easing tahap I dan III saja. 
Tabel 4. Abnormal Return dan Cumulative Abnormal Return selama Periode Peristiwa Tahap I, II dan III

\begin{tabular}{|c|l|l|l|l|l|l|}
\hline & \multicolumn{2}{|c|}{ Tahap I } & \multicolumn{2}{c|}{ Tahap II } & \multicolumn{2}{c|}{ Tahap III } \\
\hline t & Rata-rata AR & \multicolumn{1}{|c|}{ CAR } & Rata-rata AR & \multicolumn{1}{c|}{ CAR } & Rata-rata AR & CAR \\
\hline-5 & $-0,014856$ & $-0,01486$ & 0,002870 & 0,00287 & 0,000617 & 0,000617 \\
\hline-4 & $-0,008116$ & $-0,02297$ & $-0,001557$ & 0,001313 & $-0,002410$ & $-0,00179$ \\
\hline-3 & $0,003838^{* * *}$ & $-0,01913$ & 0,003949 & 0,005262 & 0,005806 & 0,004013 \\
\hline-2 & $-0,010160$ & $-0,02929$ & 0,006390 & 0,011652 & $0,008694^{* *}$ & 0,012707 \\
\hline-1 & $0,017425^{* * *}$ & $-0,01187$ & 0,000128 & 0,01178 & 0,004691 & 0,017398 \\
\hline 0 & $-0,015931$ & $-0,0278$ & 0,003668 & 0,015448 & $0,007531^{* *}$ & 0,024929 \\
\hline 1 & $-0,011134$ & $-0,03893$ & 0,001918 & 0,017366 & 0,005712 & 0,030641 \\
\hline 2 & $-0,005632$ & $-0,04457$ & $-0,002583$ & 0,014783 & $-0,002651$ & 0,02799 \\
\hline 3 & $-0,004565$ & $-0,04913$ & $-0,002817$ & 0,011966 & $0,012885^{* * *}$ & 0,040875 \\
\hline 4 & $-0,003429$ & $-0,05256$ & $-0,000970$ & 0,010996 & 0,005818 & 0,046693 \\
\hline 5 & $-0,003967$ & $-0,05653$ & 0,005384 & 0,01638 & 0,001664 & 0,048357 \\
\hline
\end{tabular}

Keterangan: ** Signifikan pada tingkat 5\%

*** Signifikan pada tingkat 1\%

Berdasarkan data yang tercantum dalam Tabel 3, dapat dijelaskan bahwa pada tahap I, abnormal return yang positif dan signifikan terjadi $\left(\mathrm{t}_{-3}\right)$ sebesar 0,0038 dan ( $\left.\mathrm{t}_{-1}\right)$ sebesar 0,0174. Reaksi pasar dari peristiwa pengumuman kebijakan quantitative easing tahap I pada harga saham yang diteliti belum terlalu kuat karena hanya terdapat dua abnormal return positif dan masih terdapat banyak abnormal return negatif disekitar tanggal peristiwa pengumuman quantitaive easing tahap I.

Akan tetapi, hasil pengujian menunjukkan bahwa peristiwa pengumuman tersebut mempunyai kandungan informasi bagi pemodal, terlihat dari adanya respon yang diberikan pemodal yang lebih cepat terhadap pasar. Respon yang cepat tersebut terlihat dari nilai abnormal return yang tinggi dibandingkan hari-hari lainnya yaitu pada tanggal $t-$ 1. Abnormal return yang positif pada $t-3$ kemungkinan diakibatkan dari peristiwa lain yang terjadi bersamaan di periode peristiwa I. Berdasarkan indeks berita detik.com pada tanggal 21 November $2008(t-3)$ beberapa indeks saham di Amerika Serikat mengalami kenaikan yang relatif cukup tinggi sebagai dampak dari pernyataan Presiden Amerika Serikat terpilih, Barack Obama, yang akan memilih Timothy Geithner sebagai Menteri Keuangan Amerika Serikat. Pasar modal Indonesia yang terkointegrasi dengan pasar modal Amerika Serikat mengalami dampak yang sama pada pernyataan yang dikeluarkan oleh Obama tersebut, sehingga pada $t-3$ terjadi abnormal return positif dan signifikan.

Pada tahap II, sampel saham-saham yang diteliti lebih banyak mempunyai nilai abnormal return positif namun tidak signifikan. Hasil semacam ini tidak sesuai dengan harapan penelitian, informas mengenai kebijakan moneter ekspansif yang dikeluarkan The Fed seharusnya memberikan pengaruh pada return yang positif saham-saham yang diperdagangkan di BEI. Hasil pengujian yang tidak signifikan berarti tidak ada abnormal return pada sampel saham yang diteliti atau abnormal return sama dengan nol (0). Pemodal menganggap informas yang diterima mengenai kebijakan quantitative easing tahap II bukan sebagai informasi yang baru.

Pada tahap III, hampir seluruh nilai abnorma return disekitar periode peristiwa memiliki nilai positifkecuali pada $t-4$ dant +2 . Namun, abnorma return positif dan signifikan hanya terdapat pada $t-2(0,008694), t 0(0,007531)$, dan $t+3(0,012885)$ Abnormal return di $t-2$ (tanggal 12 September 2009) merupakan reaksi pasar atas keputusan pengadilan Jerman yang memberikan bailout untuk mengatasi krisis utang Uni Eropa. Informasi tersebut berdampak pada penguatan pasar saham di Eropa dan Wall Street, dan berdampak pada pasar modal di Indonesia yang telah terintegrasi dengan bursa saham internasional. Abnormal return yang positil dan signifikan pada $t+3$ merupakan respon pemodal terhadap keputusan yang dikeluarkan The Fed. Menurut analisis AAA Sekuritas sebagaimana dikutip detik finance menyatakan bahwa sampai dengan tanggal 19 September 2012 pemodal bersikap wait and see, menunggu hasil pemilihan Presiden Amerika Serikat. Hal tersebut didukung dengan pergerakan bursa saham Amerika Serikat yang cenderung bergerak sideways.

Berdasarkan analisis, pemodal telah melakukan antisipasi sebagai dampak informasi yang terlebih dahulu diterima pemodal, sehingga pemoda] melakukan respon lebih cepat sebelum keputusan 
The Fed diumumkan. Hal tersebut didukung penelitian yang dilakukan Husnan (1996) yang menyatakan bahwa keuntungan abnormal return (abnormal return yang positif) tidak akan diperoleh sesudah terjadi peristiwa. Keuntungan abnormal return sebelum peristiwa dimungkinkan karena adanya antisipasi dari pemodal atau kebocoran informasi yang telah diperoleh pemodal sebelumnya.

Pengujian trading volume activity digunakan untuk membuktikan adanya perbedaan intensitas perdagangan setelah The Fed mengumumkan kebijakan quantitative easing. Hasil pengujian trading volume activity menunjukkan adanya perbedaan intensitas perdagangan yang lebih besar antara periode sesudah dan sebelum pengumuman peristiwa. Sebagaimana pengujian menggunakan abnormal return, pengujian menggunakan trading volume activity membuktikan bahwa pengumuman kebijakan quantitative easing pada tahap I dan III dianggap memiliki kandungan informasi sehingga pemodal memberikan reaksi dengan melakukan aktivitas perdagangan yang lebih besar pada periode setelah pengumuman kebijakan tersebut.

Grafik 1 Intensitas Perdagangan pada Peristiwa Quantitative Easing Tahap I, II dan III

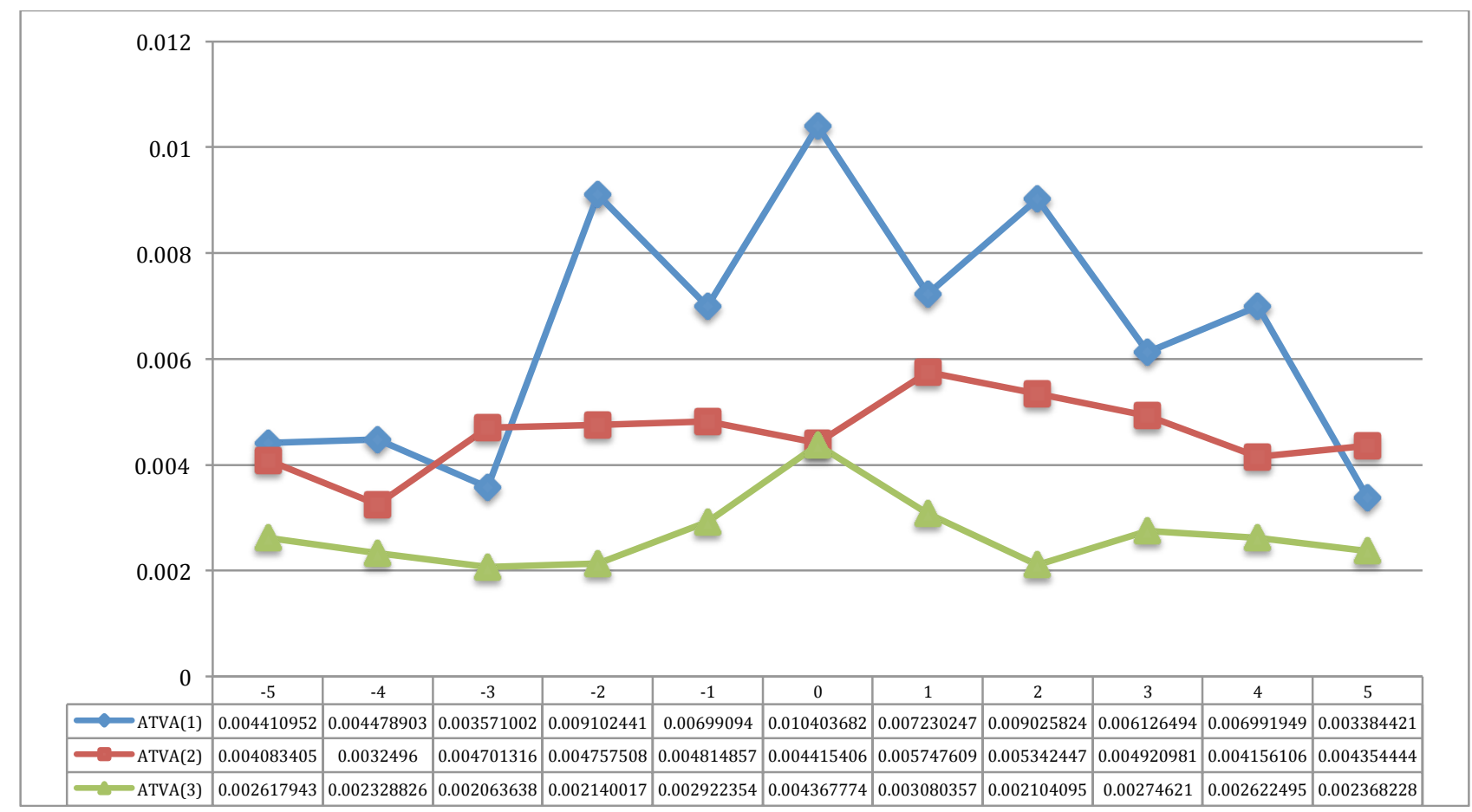

Grafik 1 secara umum menunjukkan terjadinya peningkatan intensitas perdagangan pada periode peristiwa tahap I dan III yang dimulai dari $t-3$ sampai dengan $t+3$. Pada periode tersebut, tanggal peristiwa ( $t 0)$ tahap I dan II terjadi intensitas perdagangan tertinggi dibandingkan hari-hari lain pada periode peristiwa, sedangkan pada periode peristiwa II intensitas perdagangan saham- saham yang diteliti mengalami pergerakan yang cenderung datar. Hal tersebut selaras dengan hasil pengujian trading volume activity yang menyatakan bahwa pada tahap II tidak ada perbedaaan yang lebih besar setelah peristiwa pengumuman kebijakan, pemodal tidak melakukan respon atas peristiwa pengumuman kebijakan quantitative easing.

\section{KESIMPULAN DAN SARAN}

Pengumuman kebijakan quantitative easing mempunyai kandungan informasi bagi pasar modal Indonesia, hal tersebut didukung karena adanya kointegrasi antara pasar modal di Amerika Serikat dan pasar modal di Indonesia yang menyebabkan peristiwa international dapat berpengaruh pada abnormal return dan intensitas perdagangan di pasar modal Indonesia. Harapan pemodal terhadap kebijakan moneter ekspansif yang diputuskan oleh The Fed adalah keuntungan melalui return saham yang positif. Oleh karena itu, berdasarkan hasil pengujian dan analisis dapat disimpulkan bahwa: (1).Kandungan informasi dari peristiwa pengumuman kebijakan quantitative easing ditunjukkan dengan abnormal return yang positif antara lain sehari sebelum $(t-1)$ peristiwa tahap I, 
dan $t-2$, t0 dan $t+3$ sesudah peristiwa tahap III, (2).Terjadi intensitas perdagangan yang lebih besar pada periode setelah peristiwa pengumuman kebijakan quantitative easing tahap I dan III, dan trading volume activity tertinggi pada tanggal peristiwa ( $t 0)$ di tahap I dan III. Hasil ini mendukung kesimpulan pertama dan membuktikan bahwa pengujian efisiensi pasar secara informasi di pasar modal Indonesia dapat dinyatakan sebagai pasar modal yang efisien secara informasi dalam bentuk setengah kuat, (3).Pemodal tidak dapat menggunakan informasi yang dipublikasikan tersebut untuk mendapatkan keuntungan (abnormal return positif) dalam jangka waktu yang lama (hanya disekitaran tanggal peristiwa), hal tersebut juga dibuktikan dengan intensitas perdagangan yang meningkat hanya pada periode $t-3$ sampai dengan $t+3$.

\section{IMPLIKASI DAN KETERBATASAN}

Penelitian selanjutnya dapat dilakukan dengan menguji perbedaan abnormal return dan trading volume activity berdasarkan kelompok sampel saham yang memiliki posisi net buying dan net selling oleh pemodal asing. Keterbatasan data net buying dan selling per sekuritas secara harian menyebabkan pengujian hipotesis adanya keterkaitan aliran modal asing yang terjadi disekitar tanggal peristiwa sebagai dampak limpahan likuidas akibat adanya kebijakan quantitative easing tidak dapat dibuktikan

\section{DAFTAR PUSTAKA (REFERENCES)}

Abimanyu, Yoopi et al (2008), International Linkages to The Indonesian Capital Market: Cointegration Test. Jakarta: Capital Market and Financial Institution Supervisory Agency.

Badan Pengawas Pasar Modal dan Lembaga Keuangan (2008), Analisis Hubungan Kointegrasi dan Kausalitas Serta Hubungan Dinamis Antara Aliran Modal Asing, Perubahan Nilai Tukar dan Pergerakan IHSG di Pasar Modal Indonesia. Jakarta: Bapepam-LK.

Beaver, William H. (1968), "The Information Content of Annual Earnings Announcements", Journal of Accounting Research, Vol. 6, hlm. 67-92

Bodie, Zvi et al (2011), Investment and Portofolio Management, $9^{\text {th }}$ edition. New York: McGraw Hill

Conover, C. Mitchell et al (2005), "Is Fed Policy Still Relevant for Investors?" Financial Analysts Journal, Vol. 61, No. 1, hlm. 70-79.

Dyckman, Thomas et al (1984), "A Comparison of Event Study Methodologies Using Daily Stock Returns: A Simulation Approach", Journal of Accounting Research, Vol. 22, Studies on Current Econometric Issues in Accounting Research, hlm. 1-30.
Hartono, Jogiyanto (2013), Teori Portofolio dan Analisis Investasi, Edisi ke-8. Yogyakarta: BPFE.

Husnan, Suad et al (1996), "Dampak Pengumuman Laporan Keuangan Terhadap Kegiatan Perdagangan Saham dan Variabilitas Tingkat Keuntungan", Kelola, No. 11/V/1996, hlm. 110125.

Morse, Dale (1981), "Price and Trading Volume Reaction Surrounding Earnings Announcements: A Closer Examination", Journal of Accounting Research, Vol. 19, No. 2, hlm. 374-383.

Rigobon, Roberto and Brian Sack (2003), "Measuring the Reaction of Monetary Policy to the Stock Market", The Quarterly Journal of Economics, Vol. 118, No. 2, hlm. 639-669. 
Lampiran I: Statistik Deskriptif Abnormal Return pada Peristiwa Quantitative Easing Tahap I, II dan III

\begin{tabular}{|c|c|c|c|c|c|c|c|}
\hline Paket QE & $\mathbf{t}$ & $\mathbf{N}$ & Jarak & Min. & Maks. & Rata-rata & Deviasi Standar \\
\hline \multirow[t]{11}{*}{ Tahap I } & $\mathrm{t}_{-5}$ & \multirow{11}{*}{42} & 0,1626 & $-0,0860$ & 0,0766 & $-0,014856$ & 0,0416783 \\
\hline & $\mathrm{t}_{-4}$ & & 0,1710 & $-0,0685$ & 0,1025 & $-0,008116$ & 0,0413236 \\
\hline & $\mathrm{t}_{-3}$ & & 0,2948 & $-0,1466$ & 0,1482 & 0,003838 & 0,0633209 \\
\hline & $\mathrm{t}_{-2}$ & & 0,2983 & $-0,1058$ & 0,1925 & $-0,010160$ & 0,0590124 \\
\hline & $\mathrm{t}_{-1}$ & & 0,3115 & $-0,1146$ & 0,1969 & 0,017425 & 0,0712066 \\
\hline & $\mathrm{t}_{0}$ & & 0,2980 & $-0,1303$ & 0,1678 & $-0,015931$ & 0,0507928 \\
\hline & $t_{+1}$ & & 0,2417 & $-0,1030$ & 0,1387 & $-0,011134$ & 0,0573133 \\
\hline & $t_{+2}$ & & 0,2991 & $-0,1262$ & 0,1728 & $-0,005632$ & 0,0596849 \\
\hline & $t_{+3}$ & & 0,2281 & $-0,0799$ & 0,1482 & $-0,004565$ & 0,0411818 \\
\hline & $t_{+4}$ & & 0,1295 & $-0,0727$ & 0,0567 & $-0,003429$ & 0,0303661 \\
\hline & $t_{+5}$ & & 0,2579 & $-0,0949$ & 0,1631 & $-0,003967$ & 0,0432923 \\
\hline \multirow[t]{11}{*}{ Tahap II } & $\mathrm{t}_{-5}$ & \multirow{11}{*}{40} & 0,0987 & $-0,0341$ & 0,0646 & 0,002870 & 0,0194309 \\
\hline & $\mathrm{t}_{-4}$ & & 0,0752 & $-0,0361$ & 0,0391 & $-0,001557$ & 0,0157789 \\
\hline & $\mathrm{t}_{-3}$ & & 0,1240 & $-0,0514$ & 0,0726 & 0,003949 & 0,0223819 \\
\hline & $\mathrm{t}_{-2}$ & & 0,0804 & $-0,0366$ & 0,0438 & 0,006390 & 0,0171157 \\
\hline & $\mathrm{t}_{-1}$ & & 0,0949 & $-0,0490$ & 0,0459 & 0,000128 & 0,0177907 \\
\hline & $\mathrm{t}_{0}$ & & 0,0980 & $-0,0292$ & 0,0688 & 0,003668 & 0,0209501 \\
\hline & $t_{+1}$ & & 0,0972 & $-0,0398$ & 0,0574 & 0,001918 & 0,0217777 \\
\hline & $t_{+2}$ & & 0,0984 & $-0,0428$ & 0,0556 & $-0,002583$ & 0,0230933 \\
\hline & $t_{+3}$ & & 0,1110 & $-0,0430$ & 0,0680 & $-0,002817$ & 0,0231372 \\
\hline & $\mathrm{t}_{+4}$ & & 0,0960 & $-0,0382$ & 0,0578 & $-0,000970$ & 0,0169830 \\
\hline & $t_{+5}$ & & 0,0829 & $-0,0191$ & 0,0638 & 0,005384 & 0,0166862 \\
\hline \multirow[t]{11}{*}{ Tahap III } & $\mathrm{t}_{-5}$ & \multirow{11}{*}{45} & 0,0923 & $-0,0464$ & 0,0459 & 0,000617 & 0,0183716 \\
\hline & $\mathrm{t}_{-4}$ & & 0,0929 & $-0,0426$ & 0,0503 & $-0,002410$ & 0,0194194 \\
\hline & $\mathrm{t}_{-3}$ & & 0,0789 & $-0,0182$ & 0,0608 & 0,005806 & 0,0147304 \\
\hline & $\mathrm{t}_{-2}$ & & 0,1021 & $-0,0186$ & 0,0835 & 0,008694 & 0,0218211 \\
\hline & $\mathrm{t}_{-1}$ & & 0,0928 & $-0,0237$ & 0,0692 & 0,004691 & 0,0195907 \\
\hline & $\mathrm{t}_{0}$ & & 0,0964 & $-0,0264$ & 0,0700 & 0,007531 & 0,0224017 \\
\hline & $t_{+1}$ & & 0,1081 & $-0,0447$ & 0,0634 & 0,005712 & 0,0211432 \\
\hline & $t_{+2}$ & & 0,0433 & $-0,0247$ & 0,0186 & $-0,002651$ & 0,0104803 \\
\hline & $t_{+3}$ & & 0,1607 & $-0,0245$ & 0,1362 & 0,012885 & 0,0305375 \\
\hline & $\mathrm{t}_{+4}$ & & 0,2023 & $-0,0349$ & 0,1674 & 0,005818 & 0,0285191 \\
\hline & $t_{+5}$ & & 0,0988 & $-0,0327$ & 0,0661 & 0,001664 & 0,0184708 \\
\hline
\end{tabular}


Lampiran II: Statistik Deskriptif Trading Volume Activitypada Peristiwa Quantitative Easing Tahap I, II dan III

\begin{tabular}{|c|c|c|c|c|c|c|c|}
\hline Paket QE & $\mathbf{t}$ & $\mathbf{N}$ & Jarak & Min. & Maks. & Rata-rata & Standar Deviasi \\
\hline \multirow[t]{11}{*}{ Tahap I } & $\mathrm{t}_{-5}$ & \multirow{11}{*}{42} & 0,0459 & 0,0000 & 0,0459 & 0,004414 & 0,0086239 \\
\hline & $\mathrm{t}_{-4}$ & & 0,0569 & 0,0000 & 0,0569 & 0,004476 & 0,0094303 \\
\hline & $\mathrm{t}_{-3}$ & & 0,0461 & 0,0000 & 0,0461 & 0,003569 & 0,0075801 \\
\hline & $\mathrm{t}_{-2}$ & & 0,1661 & 0,0000 & 0,1661 & 0,009102 & 0,0262790 \\
\hline & $\mathrm{t}_{-1}$ & & 0,1000 & 0,0000 & 0,1000 & 0,006988 & 0,0180441 \\
\hline & $\mathrm{t}_{0}$ & & 0,1437 & 0,0000 & 0,1437 & 0,010405 & 0,0237841 \\
\hline & $t_{+1}$ & & 0,0796 & 0,0000 & 0,0796 & 0,007224 & 0,0147712 \\
\hline & $t_{+2}$ & & 0,1456 & 0,0000 & 0,1456 & 0,009024 & 0,0232608 \\
\hline & $t_{+3}$ & & 0,0483 & 0,0000 & 0,0483 & 0,006129 & 0,0099489 \\
\hline & $t_{+4}$ & & 0,0895 & 0,0000 & 0,0895 & 0,006998 & 0,0145975 \\
\hline & $t_{+5}$ & & 0,0457 & 0,0000 & 0,0457 & 0,003386 & 0,0072682 \\
\hline \multirow[t]{11}{*}{ Tahap II } & $\mathrm{t}_{-5}$ & \multirow{11}{*}{40} & 0,0297 & 0,0001 & 0,0299 & 0,004083 & 0,0064408 \\
\hline & $\mathrm{t}_{-4}$ & & 0,0259 & 0,0003 & 0,0262 & 0,003250 & 0,0049032 \\
\hline & $\mathrm{t}_{-3}$ & & 0,0587 & 0,0002 & 0,0589 & 0,004701 & 0,0099486 \\
\hline & $\mathrm{t}_{-2}$ & & 0,0434 & 0,0004 & 0,0438 & 0,004758 & 0,0078482 \\
\hline & $\mathrm{t}_{-1}$ & & 0,0455 & 0,0001 & 0,0455 & 0,004815 & 0,0095606 \\
\hline & $t_{0}$ & & 0,0398 & 0,0003 & 0,0400 & 0,004415 & 0,0074416 \\
\hline & $t_{+1}$ & & 0,0458 & 0,0001 & 0,0460 & 0,005748 & 0,0093236 \\
\hline & $t_{+2}$ & & 0,0364 & 0,0002 & 0,0365 & 0,005342 & 0,0086518 \\
\hline & $t_{+3}$ & & 0,0247 & 0,0006 & 0,0253 & 0,004921 & 0,0057666 \\
\hline & $t_{+4}$ & & 0,0451 & 0,0002 & 0,0453 & 0,004156 & 0,0079768 \\
\hline & $t_{+5}$ & & 0,0297 & 0,0004 & 0,0301 & 0,004354 & 0,0072345 \\
\hline \multirow[t]{11}{*}{ Tahap III } & $\mathrm{t}_{-5}$ & \multirow{11}{*}{45} & 0,0210 & 0,0000 & 0,0210 & 0,002618 & 0,0039921 \\
\hline & $\mathrm{t}_{-4}$ & & 0,0117 & 0,0000 & 0,0117 & 0,002329 & 0,0031130 \\
\hline & $\mathrm{t}_{-3}$ & & 0,0144 & 0,0000 & 0,0144 & 0,002064 & 0,0032055 \\
\hline & $\mathrm{t}_{-2}$ & & 0,0122 & 0,0000 & 0,0122 & 0,002140 & 0,0026362 \\
\hline & $\mathrm{t}_{-1}$ & & 0,0236 & 0,0000 & 0,0236 & 0,002922 & 0,0044674 \\
\hline & $t_{0}$ & & 0,0228 & 0,0000 & 0,0228 & 0,004368 & 0,0047350 \\
\hline & $t_{+1}$ & & 0,0183 & 0,0000 & 0,0183 & 0,003080 & 0,0034771 \\
\hline & $t_{+2}$ & & 0,0132 & 0,0000 & 0,0132 & 0,002104 & 0,0027694 \\
\hline & $t_{+3}$ & & 00141 & 0,0000 & 0,0141 & 0,002746 & 0,0032786 \\
\hline & $t_{+4}$ & & 0,0219 & 0,0000 & 0,0219 & 0,002622 & 0,0044510 \\
\hline & $t_{+5}$ & & 0,0158 & 0,0000 & 0,0158 & 0,002368 & 0,0029182 \\
\hline
\end{tabular}

